\title{
日本鉄鋼協会創立當時の回顧
}

\author{
83老鼠 俵 \\ 国 一*

\section{REMINISCENCE OF THE SITUATIONS AT ESTABLISHMENT OF THE IRON \& STEEL INSTITUTE OF JAPAN}

\author{
Kuniichi Tawara, Dr. Eng., Prof. emeritus, Univ. of Tokyo
}

\begin{abstract}
Synopsis:
The present article is a memorandum of 40 years experience of the author in the history of the Institute.

In July 8th, 1914 (Taisho-3), Messrs. Kaichiro Imaizumi, Kuniichi Tawara, Kageyoshi Noro and Koroku Komura assembled together to discuss the establishment of an Institute in view of publication of an organ periodical, installation of an laboratory and a display station and making such research as would be suitable for science and industry. On October 4th 1915 (Taisho-4) a meetlng of promoters including the aforementioned and besides Messrs. Fuji Tanaka, Masayoshi Tsutsumi, and Seiichi Terano, to discuss about the preparation.

On Feb. 6th, 1915. (Taisho-4), the inauguration meeting was held at the Building of Nippon Kogyokai, Tokyo and the enlisted members then attained to 610 persons. The directors were Messrs. Kaichiro Imaizumi, Kuniichi Tawara, Koroku Komura and Seiichi Terano, the chairman of directors being Mr. Kageyoshi Noro. The organ periodical "Tetsu-to-Hagané" (The Journal of The Iron \& Steel Institute of Japan) was first published in Mar. 1915. Since then the Journal has been published every month incessantly excepting a period from Nov. 1944 to Dec. 1945. The establishment of the Institute was entirely initiated by the merits of Dr. Prof. Noro, former professor of Tokyo Imperial University and other collaborators were all his disciples. In his later years $\mathrm{Dr}$. Noro became consultant to Tanaka (the present Kamaishi) Iron Works and the Governmental Edamitsu (the present Yawata) Iron Works to develop the blast furnace oferations and died in 1923 (Taisho-12): The special features of the Regulations of the Institute was the qualification of the Institute members, that comprehended not only the scientists, engineers, manufacturers but the sellers and users. The reason simply lies in that the iron and steel industry could not do without cooperation of the users and sales agents. This must strictly be reminded for a synthetic engineering such as the iron \& steel industry. From the first outset the author was appointed an editor of the Journal and has experienecd a number of difficulties. The other editors in cooperation were Messrs. Kajima Muroi, Yoshihiro Kawakami and Katsumi Inouye.

Beside the senior Dr. Noro. the author also recollected Drs. Imaizumi, Komura, Hattori and Tsuruo Noda, Saburo Watanabe and Takeshi Kawamura to be forerunners of the siderurgical engineers in Japan and the best contributors to development of the Institute. Some of the prize funds and the Library books of the Institute were all donations from or in memory of these forerunners.
\end{abstract}

本協会が創立されたのは大正 4 年 3 月であり, 満40周 年に当るのでその創立当明より関保した 1 人の生存者と してその模様を書くようとの依翟があつた. そこで鉄と 堸の領利号から協会の記事を拡萃する。

大正 3 年 6 月 8 日今泉嘉一郎, 俵国一, 野呂景憧, 香 村小録の4名会合し我国において鉄および鏑に関する夏

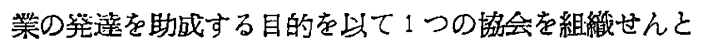
欲し势繊の結果.

（イ） 関雑誌を発行すること.
（口）協会の発展に伴い理化学的試験所お゙び参考品 陳列所を設圆するてと。

（ハ）学術上および経済上時算认適する研究調查をな すとと.

会員の資格を鉄鉱採堸業者，鉄鋼製造業者わよびその 加工者, 鉄鋼使用者, 鉄鋼販壳者ならびにてれらに関す る技汧者および従業者ぞの他鉄鋼に関係ある特志者とす

* 束京大学名誉教授, 元本会々長, 工博 
るこ己，と一応決定したのである。

大正 3 年 10 月 4 日発起人会を開学今泉一郎，田中 不二，传国一，堤正義，野吕景載，香村小録および寺野， 精一の 7 名出席し会名を日本鉄鋼揬会とするとととし， 創立主意書わよび定款草案を作製した上に広く经員募集 家開始した。

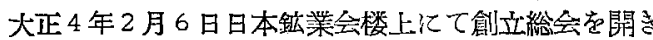
浨募会員の申込は 610 名に達した。最初は社団法人でな

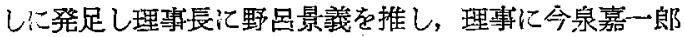

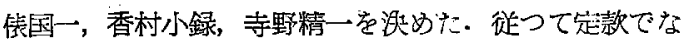
〈会則を視定した．機関噍誌を鉄“と錀と”命名し每月 1 回発行するとととし大正 4 年 3 月に創刊号を出したの で，第 1 年は 10 冊を以て終り爾来終戦当時を除每月 発刊している.

上下は私の心もとない記憶を迎り解説みたようなもの

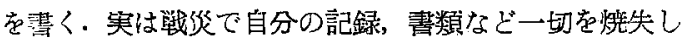
こので覚元違いの点あらば用搭願いたい。

本協会の設立は全く工学博士野吕景義先生の主唱に作 つたもので，最初の相談会をも先生が招集されたもの， 会した者皆先生の門下生であつたたしか日本銗業会の 留談会が浅草橋附近の料理屋であつた際と思う，そこで

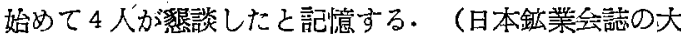
正 3 年 11 月 357 号䎲传る亿大正 3 年 6 月初め日本鉱業

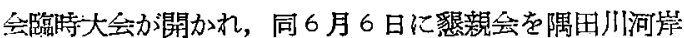
に沿つた福并楼で催したとある. その席上別室で最初に 云合したとと確完と思う.) 会則その他すべてのてと 野吕先生の意見力注に用いられた。

写呂景義先生は要知県恬身者で明治 15 年東京大学理 学部振鉣冶金科を卒業せられた・爾来東京大学の教桴と して鉄冾金学の講義をなされ，その子韵に明治 25 年率

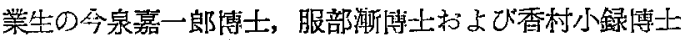
などがある。私が 2 年生のとき講義半ばで大学教授を辞 職せられた後法，釡不の田中隻鉄所ま心は朵官設技光製鉄 所の顧問などなされ，製鉄業殊に螾鉱师の作業に力を会 された。 大正 12 年末大震狟後物資不自的の時分认逝去 せられた．笑に野品先生は本邦製鉄業の発展に寄与せら れた大先輩で，また本協会の主唱者，有才なる指尊者で あつて永くその德を仰が齐ばなら如。

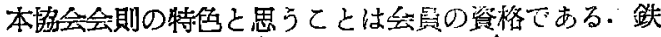

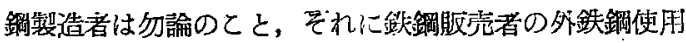

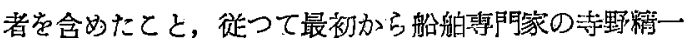
等士を理事门お願し，その後も会辰または理事として他

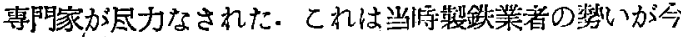
日程盛んでないにも依るが，主として铁の使用者，需用
家の協力なしには成り立たない理に基ずくと考光る。こ れは飽迄心して貲い䋿い，製鉄業のような各種専門家の. 総合技術学必要とするものでは是非心得え效ばならぬと 愚考する．そんな意味を含め、て学会といわず協会と唱え るようになつた管である。最初は理化学的試験所うよび 参考品陳列所を設ける定めであり, 野吕先生の强いての 主張であつた。とれを英施するに至らず単㐳小さな機械。 試験機を置いた位で中絶した。

自分は最初加ら会誌鉄と鋼の糄集を受持つたもので， 自ら校正をもしたし，また原稿の集め方汇苦心し鉄道䂙 究所や瓝信省船舶局の友人に愁詿したてともある. 野呂 先生の創刊号より尰続 17 回任亘る長篇「本邦製鉄事業 の過去および捋来」と題する論文を寄方れるのを有難 く思つた．会誌の表紙にある「鉄と鋼」の文字は䗢か香 村小録博上が某書家に頼まれたもの之記憶する。会誌の，

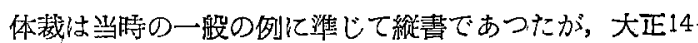
年すなわち第 11 年より現在の横書となつた.その時分 に種々編集事務など助けて下されたのは海軍技研の窒开 嘉治馬氏，陸軍の川上義弘博士ならごに大学の井上克已 博士らである. 垈氏其㳊昭和 20 年 4 月に本協会より協 会踕業の振興発造江対する貢献に酬ゆるため表彰状を受 領せられた。

野鱼大先韭の外纪今泉博士，香村博士および服部博士 等は私の脳裡に永く製鉄技術者の 3 先覚者として敬慕し た方である.今泉博士は技光製鉄所の製銅部長として令 各あり，楆に下りて日本鋼管椌式会社を創豆なされ，㙁 基性䡉紧法を始めて本邦にて行われたのは第知の通りで ある. この縁伅作り日本鋼管株式会社寄贈資金および故 今家溥上記念餐金ができた。香村博士は大学卒業後鉒石 四中製鉄所汇赴任せられ，当時唯一の製鉄所において努 万経営なされた後東京に在蜮本会のため尽力せられた。 また榑士は私財它劄贈せられ，本会恃香村博士寄贈資金 取扱覞則を制定した．創立当時服部博士挝遠く九州技光 製鉄所に罣務されていたため直接に会務に関与されなか つたが，真京転勤の上は会長の職につかれ会のため尽さ れた。服部博士記念資金寄附者の禺出に基き本云にその 取报覞則ができた。

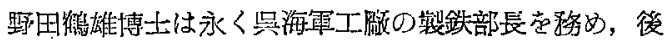
八幡製鉄所の技監となられ昭和9 年日本製鉄株式会社東 京本性在勤，会長化就任し尽力せられた．記念事業とし て资金案募集してれを体会に等贈し野田文庫を纹立する ことになつた，俵博士記念资金取扱規則なるるのが市 万. 昭和 7 年東京大学退職你し知人の方々が募集して 下さつた一部の金員を本会汇美し田し，偍秀なる猃文に 
対する奖励に使われる．誠に有睢いし痛み入るてとであ る・渡跀三郎博士は日本特殊鋼株式会社の創立者, 本邦 特殊鍕製造発展に功労のある方である. 本会長として尽 力せられ金員を寄与せられ，本会は日本特殊鋼株式会社 寄贈資金取扱規則を制定している，その外に河村䜿博士 は会歌に照命に努力せられた方で，2回も会長につかれ． その務め先が三蒙製鉄会社で近くであつたため常に会務 を指導せられた功䋶は大きい，また博上は私財を本会に 寄贈せられ毎十周年每に本会記念祝賀会に使用するよう に浃定した取扱規則ができている：今次終戦の際に恰も 華北の製銑業顧問として北京に滞在しておられ，引止の
ため太沽に待合せ中種及の困難に遇われた結果不幸病没，

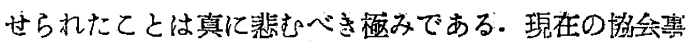
務所も全く同博士の䲩打で洪つたものだ。

斯く本拹会創立当侍の記事を読んで見ても生存者は目 分独りで揤汃細い，顧みて各先輩の努力せられた际が

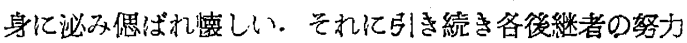

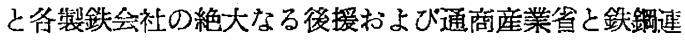
盟との協力を得て協会力今日益々隆盛となるを祝し得る

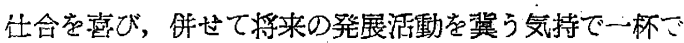
ある.

戰後における本邦鉄鋼業の推移

\author{
三 井 太 佶* \\ THE POSTWAR DEVELOPMENT OF IRON \\ AND STEEL INDUSTRY IN JAPAN
}

\begin{abstract}
Takichi Mitsui
Ministry of International Trade and Industry.

Synopsis:

Among the greatest obstacles in the postwar recovery of steel industry in Japan were counted the shortage of coal, the removal of subvention to the iron and steelprices and decentralization of large steel firms. A tragic atmosphere thus clouded was pushed away by the breakout of the Korean Incident (June 1950). Again the prices became enhanced. The export was extended and the production increased. Thence came a chance of modernization of iron and-steel industry in Japan. The scheme of this plan that had been plotted by the Rationalization Council in the first half of 1951 was encouraged in the second half by establishment of Japan Development Bank, institution of special overeas credit by the Bank of Japan and the favorable development in Capital market.

Capital development and production increase of steel firms in Japan was suceessively realized during the year of 1951. However, towards 1952 the period of reaction began so that an intensification of the sales competition gradually invited a drop in the steel prices, notwithstanding a temporary short boom due to a steel strike in the United States.

In April 1952, the industrial control of the Occupation Forces ended and Japan was again allowed to enter an international economic circles.

At this moment, owing to establishment of the European Coal and Steel Community, prog. ress of modernization progress in several countries and recovery of the West-Germany iron and steel industry, the steel industry of Japan too was obliged to be entangled with the international contest.

In 1953, the steel market again tended to a slight boom due to domestic investment and consumption but at the end of the same year decrease in bath munition demands and steel export again occurred. Without finding domestic demands, the steel products of Japan began to flow out overseas. At this time happily owing to a shortage of steel export from Europe Japanese products filled the markets of South America and India and enjoyed higher prices. It was also evident at the end of 1954 that the iron and steel industry in Japan again inclined
\end{abstract}

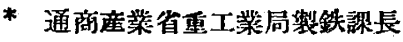

